\title{
Andragogy or Pedagogy: Views of Young Adults on the Learning Environment
}

\author{
Fatma Tezcan ${ }^{1}$ \\ ${ }^{1}$ Department of Educational Sciences, Muğla Sttkı Koçman University, Muğla, Turkey \\ Correspondence: Fatma Tezcan, Department of Educational Sciences Faculty of Education Muğla Sitkı Koçman \\ University, 48100 Menteşe, Muğla, Turkey.
}

Received: September 24, 2021

Accepted: November 26, $2021 \quad$ Online Published: January 20, 2022

doi:10.5539/ies.v15n1p136

URL: https://doi.org/10.5539/ies.v15n1p136

\begin{abstract}
Adults participate in many formal learning activities throughout their lives. The aim of this study is to determine the views of adult learners who participated the Certificate Program for Pedagogical Formation (CPPF), which is a formal adult education program. This study was conducted with the phenomenological design, a qualitative research design. The data required for the research were collected with a data collection tool developed by the researcher. In the study, the participants expressed the positive aspects of the program, in a decreasing order of frequency as, obtaining professional knowledge, faculty members, learning new things, the contribution of the program to personal life and gaining perspective. On the other hand, the participants negatively evaluated the intensive course and exam schedule, the duration of the program, the intensive and verbal content, and the length of the course hours. While the participants evaluated learning new things and gaining perspective as an achievement of the program, they expressed their dissatisfaction with the planning of the program and the learning environment related to it. In light of the findings of the study, it is recommended for policy makers to plan similar programs according to the learning characteristics of adults and make arrangements in this direction. It is also recommended for educators to consider andragogical principles in the learning environment in adult education programs such as certificate programs.
\end{abstract}

Keywords: andragogy, adult education, adult learning, teacher training, young adults, Certificate Program for Pedagogical Formation

\section{Introduction}

Learning is an integral part of daily life. Therefore, it is a concept that begins with birth and continues throughout life. Adult learning occurs mostly in informal ways, although adults participate in many formal adult education activities throughout their lives. While experiences and observations in daily life are the source of informal learning, learning activities for a specific purpose whose content and duration are structured in advance are defined as formal learning. Moreover, while formal learning involves intentionality, informal learning does not usually involve intent on the learner's part (Statistics Canada, 2008; Rogers, 2014). Many factors such as age and problems encountered in life are factors in adult learning. Therefore, formal learning activities are closely related to the needs of adults.

As a formal learning activity, the Certificate Program for Pedagogical Formation (CPPF) is attended by young adults who are studying in the last year of their university education or have graduated from university. As the participants are adults, CPPF, an adult education program, aims to provide young adults with the knowledge necessary for the profession of teaching. For this reason, it is important for the sustainability of the program to organize and execute such programs on the higher education level according to the learning principles of adults.

Furthermore, considering elements such as the organization of CPPF, determination of the content, location and time of the program, it is observed that pedagogical understanding and perspective are more effective than adult learning principles. Hence, this article first discusses andragogy which offers principles upon the learning processes of adults, with its main aspects, and the importance of the realization of a certification program based on adult learning principles, are discussed in the context of CPPF, a part of the teacher training system in Turkey.

\section{1 "Adults Can Learn": The Path to Andragogy}

Learning is a concept that exists in life and people constantly learn throughout their lives. The idea that learning 
continues in adulthood, has paved the way for the first studies on adult learning in the early 1900s. In that period, who an adult is and an adult's characteristics in terms of learning were examined in depth. In Merriam's (2001) words, the question that framed much of the early research on adult learning was whether or not adults could learn. From the 1920s to the 1970s, when the first studies on adult learning began, studies on adult learning for the last fifty years gained a new dimension with andragogy, which includes a series of principles on adult learning. Andragogy is derived from the Greek word "man" and has been described by Knowles as the science and art of helping adults learn (Jarvis, 1990). While establishing a learning model for adults, Knowles, in his early work, adopted the idea that the andragogical model is the antithesis of the pedagogical model and discussed the andragogical approach based on pedagogy (Glassner \& Back, 2020; Knowles, 1996).

In the pedagogical model, the whole responsibility of what is learned, how it is learned, when it is learned and whether it is learned falls upon the teacher. In the teacher-centered pedagogical model, the only role of the learner is to comply with the teacher's instructions (Knowles, 1996; Knowles, Holton, \& Swanson, 2005). The pedagogical model positions learners as objects rather than subjects in the learning environment. In this respect, the pedagogical model corresponds to the traditional rote learning system defined by Freire (2014) as banking education. Therefore, the banking education model is the conceptualization of the teacher-centered pedagogical model and rote system. The understanding of education proposed by Freire (2014, p. 65) in response to banking education is problem-posing education in which learners are subjects and dialogue stands out. In this sense, problem-posing education, which considers the learner's self-perception, becomes important for adults to learn.

The degree of dependence, which is high in the first years of an individual's life, decreases towards adolescence and then leaves its place to self-directed behavior to a large extent. In this sense, psychological adulthood means being responsible for one's own life. Knowles (1996) drew attention to psychological maturity in terms of learning and stated that the self-directed ego begins to develop at the early stages of an individual's life. Knowles defined andragogical principles as "systems of concepts" rather than theory, and many educational theoreticians have had an influence on these principles (Blondy, 2007). In the andragogical learning model, the principles developed by Knowles regarding adult learning are as follows (Knowles, 1996; Knowles, Holton, \& Swanson, 2005):

1) Need to know: Adults need to know why they should learn before they can learn something. Therefore, the first task of the facilitator is to help learners become aware of their need to know.

2) Learners' self-perception: Adults take responsibility for their own decisions and lives and have a deep psychological need to be treated accordingly. Therefore, while organizing learning experiences for adults, one should pay sufficient attention to the fact that they are self-directed learners.

3) The role of learners' experiences: Adults participate in an educational activity with more experiences and different experiences than young people. Experiences that differ in quality and quantity in adult learning have various consequences for adult education. Therefore, experiential techniques such as group discussions and case methods should be emphasized in adult education.

4) Readiness to learn: Adults are prepared to learn what they need to know to cope with the problems they face in life. Developmental tasks for adulthood are a rich resource for readiness to learn.

5) Orientation towards learning: The learning orientation of adults is life/task- or problem-oriented, contrary to the subject-oriented learning of children and young people. The extent of adults to learn depends on their realization that learning helps them fulfil the tasks in their lives or cope with the problems they face. Accordingly, adults learn when new information is most effectively presented in the context of their applicability to real-life situations.

6) Motivation to learn: While adults react to some external motivators (e.g., advance payments, a higher wage, better working conditions), the most powerful motivators are internal ones (e.g., a greater desire for job satisfaction, self-esteem, quality of life). 
Table 1. Pedagogy and andragogy

\begin{tabular}{lll}
\hline \multicolumn{1}{c}{$\begin{array}{c}\text { Andragogical } \\
\text { Principles }\end{array}$} & \multicolumn{1}{c}{ Pedagogy } & Andragogy \\
\hline The need to know & $\begin{array}{l}\text { Learners do not need to know what and why they } \\
\text { need to learn }\end{array}$ & Learners want to know what and why they need to learn \\
\hline $\begin{array}{l}\text { Learner's } \\
\text { self-perception }\end{array}$ & Dependent personality & Self-directedness \\
\hline Role of experience & Experiences play little role & The role of experiences is a rich resource for learning \\
\hline Readiness to learn & Learners are ready to learn what they have to learn & Learners are ready to learn what they need to learn \\
\hline $\begin{array}{l}\text { Orientation towards } \\
\text { learning }\end{array}$ & Subject-oriented & Life/task/problem-oriented \\
\hline Motivation to learn & $\begin{array}{l}\text { External motivations (parental pressure, teacher's } \\
\text { approval or rejection, grades) }\end{array}$ & $\begin{array}{l}\text { Internal motivations (job satisfaction, self-confidence, } \\
\text { self-esteem, quality of life) }\end{array}$ \\
\hline
\end{tabular}

Source: Knowles (1996, pp. 56-62).

Knowles (1996) stated that there are better learners in the andragogical model on the school education level; however, it is the educators' responsibility to use pedagogical and andragogical models in a learning environment. He also added that it is appropriate to apply the pedagogical model at least as a starting point in some programs for adults. Accordingly, "the pedagogical model is an ideological model that excludes andragogical assumptions. The andragogical model is a system of assumptions that includes pedagogical assumptions" (Knowles, Holton \& Swanson, 2005, p. 72). Therefore, andragogy is an inclusive model. The andragogical model has been discussed and studied by many authors afterwards. Merriam (2001) expressed andragogy, along with self-directed learning, as two foundational theories that are important components of our present-day understanding of adult learning. "Facilitation, self-directed learning, andragogy and adult learning principles all focus on the importance of developing a teaching and learning process that supports and encourages adult learners" (Nesbit, Leach, \& Foley, 2004, pp. 88-89). According to Jarvis (2004), Knowles was an important practitioner in the education of adults, and the implications of andragogy are quite profound for the practice of teaching adults. In terms of the age period of the participants, the level of higher education is a part of adult education, and there are many studies that evaluated young adults within the scope of adult education and learning (Kasworm, 2018; Toiviainen, Kersh \& Hyytiä, 2019). As a matter of fact, studies on young adults on the level of higher education have shown that the tendency towards learner-centered andragogy has increased (Livingston-Galloway \& George, 2020; McNally et al., 2019; Santos, Figueiredo, \& Vieira, 2019). Accordingly, the adoption of andragogical approaches in educational activities and learning environments from the beginning of young adulthood, which is also the first period of adulthood, positively affects learning by increasing participation and interest.

\subsection{The Certificate Program for Pedagogical Formation (CPPF) as a Part of the Teacher Training System in Turkey}

In Turkey, which has a long history of teacher training (Akyüz, 2019), special attention is paid to this field of education since the establisment of the Republic, and in this period, it is possible to mention several teacher training practices. Recent practices in this field include "the production of new certificate programs", which is one of the regulations introduced by the cooperation of World Bank (WB) and the Council of Higher Education (CoHE) in 1997 (Güven, 2014, p. 66; Okçabol, 2005, p. 130). Accordingly, in certificate programs, those who graduate from four-year programs other than teaching programs "can become teachers in the relevant field by taking the courses determined by CoHE" (Okçabol, 2009, p. 234). Regarding the certificate program, "as of 2013-2014, it has been decided to admit students centrally by the Center of Assessment Selection and Placement within the quotas to be allocated according to the fields" (Güven, 2014, p. 87). CoHE (2015) has determined and announced the procedures and principles regarding how CPPF will be carried out.

CPPF, which is an adult education program in terms of its participants, allows individuals who have graduated from four-year university programs other than teaching-related programs such as health, justice, and economics, especially at science and literature faculties, to become teachers in their fields (CoHE, 2015). In Turkey, studies related CPPF have been conducted in the context of the program itself (Demirtaş \& Kırbaç, 2016), the ideal teacher perception (Alpan, Demirkan, Koç-Erdamar, Yazçayır, \& Saraçoğlu 2019), attitudes the profession of teaching (Özkan, 2012), the pedagogical formation needs of faculty members (Korkut, 1999), views on teaching practice (Kılınç, Kılcan, \& Çepni, 2018; Tepeli \& Caner, 2014), evaluation of the program (Gürol, Türkan, \& 
Som, 2018) and problems related to the program and solution proposals (Köse, 2017).

In the literature, there is no study evaluating CPPF from the perspective of adult learning. Organizing such programs on the level of higher education according to the learning principles of adults will serve the aims of these programs. The evaluation of CPPF from the perspectives of young adults participating in the program makes this study significant. Therefore, this study is expected to contribute to the literature in the context of creating learning environments of young adults participating in CPPF based on adult learning principles.

\subsection{Aim of the Research}

Planning and executing certificate programs such as CPPF, based on the needs of adults and adult education principles, will be decisive in the success of such programs. In this sense, determining the views of adults about the organization of the program will contribute to the development of such programs. Therefore, the aim of this study is to determine the views of young adults participating in CPPF on the planning and execution of the program. In accordance with this purpose, answers were sought to the following questions:

1) What are the contributions of the Certificate Program for Pedagogical Formation according to young adults?

2) What are the difficulties of the Certificate Program for Pedagogical Formation according to young adults?

\section{Method}

\subsection{Design}

In this study, a qualitative research approach was adopted. In addition to focusing on "events, phenomena or behaviors that occur in the natural environment", qualitative research helps researchers obtain a broad perspective and have in-depth information on a subject (Büyüköztürk, Kılıç Çakmak, Akgün, Karadeniz \& Demirel, 2008, p. 201). In this study, the phenomenology design, which is a qualitative research design, was used. This design focuses on the phenomena that we are aware of but of which we do not have an in-depth and detailed understanding (Yıldırım \& Şimşek, 2005, p. 72). In phenomenological research, the researcher describes the experiences of individuals related to a phenomenon as defined by the individuals themselves (Creswell, 2017, p. 14). In this study, the data were collected using a semi-structured interview form.

\subsection{Sample}

Typical case sampling, purposive sampling method, was used to determine the sample. The purpose of typical case sampling is to work on a specific topic or situation to highlight key issues that need to be considered in the development of this topic or situation (Patton, 2018). Accordingly, adult learners taking the elective course named Lifelong Learning among the participants of the CPPF at a university formed the sample. While determining the sample, it was made sure that the group consisted of adults at different ages and from different occupations, continuing their education or graduated, as well as taking the same elective course. The sample consisted of 69 participants who attended CPPF at a university.

The distributions of the demographic characteristics of the participants are shown in Table 2. 
Table 2. Demographic characteristics of the sample

\begin{tabular}{|c|c|c|c|c|}
\hline Branch & Gender & \multicolumn{2}{|l|}{ Age } & Occupation \\
\hline \multirow{6}{*}{ Mathematics } & \multirow{6}{*}{$23 \mathrm{~F}, 5 \mathrm{M}$} & Range & $\mathrm{f}$ & \\
\hline & & $20-25 \mathrm{Y}$ & 23 & \multirow{5}{*}{$\begin{array}{l}\text { Student: } 24 \\
\text { Employed: } 4\end{array}$} \\
\hline & & $26-30 \mathrm{Y}$ & 3 & \\
\hline & & $31-35 \mathrm{Y}$ & 2 & \\
\hline & & $36-40 \mathrm{Y}$ & 0 & \\
\hline & & $40+\mathrm{Y}$ & 0 & \\
\hline \multirow{5}{*}{ Chemistry } & \multirow{5}{*}{$4 \mathrm{~F}, 2 \mathrm{M}$} & $20-25 \mathrm{Y}$ & 2 & \\
\hline & & $26-30 \mathrm{Y}$ & 3 & Student: 3 \\
\hline & & $31-35 \mathrm{Y}$ & 0 & Unemployed: 2 \\
\hline & & $36-40 \mathrm{Y}$ & 0 & Employed: 1 \\
\hline & & $40+\mathrm{Y}$ & 1 & \\
\hline \multirow{5}{*}{ Turkish Language and Literature } & \multirow{5}{*}{$22 \mathrm{~F}, 13 \mathrm{M}$} & $20-25 \mathrm{Y}$ & 28 & \multirow{5}{*}{$\begin{array}{c}\text { Student: } 26 \\
\text { Employed: } 5 \\
\text { Unemployed: } 3 \\
\text { Other: } 1\end{array}$} \\
\hline & & $26-30 \mathrm{Y}$ & 3 & \\
\hline & & $31-35 \mathrm{Y}$ & 3 & \\
\hline & & $36-40 \mathrm{Y}$ & 1 & \\
\hline & & $40+Y$ & 0 & \\
\hline
\end{tabular}

Note. $\mathrm{F}=$ Female; $\mathrm{M}=\overline{\text { Male. }}$

Table 2 shows that the majority of the participants were women, 20-25 years old and still students. In other words, the majority of the participants in the sample were in the 20-30 age range, which is defined as young adulthood (Onur, 2006).

\subsection{Data Collection Tool and Data Collection Process}

In this study, a semi-structured interview form, which was created after the review of the relevant literature and included open-ended questions, was used to obtain in-depth information about the experiences, thoughts, knowledge and feelings of the participants (Patton, 2018). The form had two parts. The first part included questions on the demographic characteristics of the participants. The second part included two questions to determine the views of the participants about the program. The semi-structured interview form was finalized for application in the sample after obtaining the opinion of a field expert.

The data were collected in the fourth week of the seven-week program. The clarification of the participants' experiences and views about the program was decisive in the timing of data collection to obtain realistic answers to the research questions. In accordance with research ethics principles, the aim and design of the study were explained to the participants before collecting data (Glesne, 2015). It was emphasized that the answers given to the interview form questions would not be used outside the study. The participants were ensured that their identifing information would not be collected.

\subsection{Data Analysis}

The content analysis approach was used to analyze the data. "The main purpose in content analysis is to reach the concepts and relationships that can explain the collected data" (Yıldırım \& Şimşek, 2005, p. 227). In content analysis, data that are similar to each other are brought together within the framework of certain concepts and themes and interpreted in a way that the reader can understand (Yıldırım \& Şimşek, 2005).

In the process of analyzing the data that were collected in this study, firstly, numerical codes were given to the participants. In the results section, the participant numbers and names of the branch groups of the participants (Turkish Language and Literature-TLL, Mathematics, Chemistry) are given at the end of the direct quotes. Then, the answers given to the questions in the interview form are described by the researcher with an inductive approach. Accordingly, the data were coded and themes (categories) were created from these codes. The data were organized according to the codes and themes and then interpreted (Merriam, 2013; Ylldırım \& Şimşek, 2005). While coding, the frequency of each expression was determined, and results were listed in the tables in an order from the most frequently repeated expressions to the least frequently repeted ones.

Validity in qualitative research refers to the researcher's control for the accuracy of the findings through certain processes (Creswell, 2017). In order to ensure the validity of the study, the collected data were reported in detail, and the findings were supported by direct quotations (Yıldırım \& Şimşek, 2005). Within the scope of the internal 
validity of the study, the data were reviewed by an expert, and the findings were audited by the researcher (Merriam, 2013). The concepts that formed the themes (codes) and the themes themselves were compared to each other and to ensure the consistency of the findings. The significance and consistency of the data were tested. Within the scope of the external validity of the study, the research process and stages, the sample was explained in detail, the findings were compared to those reported in previous studies, and it was aimed to reach actual situations (Büyüköztürk et al., 2008). One of Gibbs' (2007; cited in Creswell, 2017) recommendation about the reliability testing processes in qualitative research is the comparison of the codes developed by different coders and their results. Accordingly, using the formula (reliability=agreement/(agreement+disagreement)) proposed by Miles and Huberman (1994) to ensure internal reliability in the study, the rate of agreement between the coders was found as $84 \%$. Miles and Huberman recommended that the fit level be at least $80 \%$ for qualitative reliability (Creswell, 2017). In order to ensure internal reliability in this study, all raw data and direct quotes that supported the data are presented in the results section (Yıldırım \& Şimşek, 2005). Ellipses in parentheses (...) were used for the parts that were not included in the quotes. In order to ensure external reliability in the study, the participants who were the sources of the data collected in this study were defined by their demographic characteristics, and it was aimed to reveal the typical participant profile. The data collection tools, raw data, coding and inferences were kept for the external reliability of the study (Yıldırım \& Şimşek, 2005).

\section{Results}

\subsection{Contributions of the Certificate Program for Pedagogical Formation According to the Participants}

The participants were asked about the contributions of CPPF and findings on their "positive views about the program" were obtained. The positive views of the participants about the program were organized under four themes: learning, program planning, personal and social development, and employment. In the positive views about the program, the highest frequency was in the statements of the participants about obtaining professional knowledge in the theme of learning $(\mathrm{f}=25)$. The highest frequency in the theme of program planning was about the responses of faculty members $(\mathrm{f}=9)$, while it was about contribution to personal life $(\mathrm{f}=6)$ and gaining perspective ( $\mathrm{f}=6)$ in the theme of personal and social development. The participants also rated the program positively in terms of providing job opportunities under the theme of employment. Table 3 reflects the positive views of the participants about the program.

Table 3. Positive views of the participants about the program

\begin{tabular}{llcc}
\hline Themes Learning & $\mathrm{F}$ & $\%$ \\
\hline 1 & Obtaining professional knowledge & 25 & 36 \\
\hline 2 & Learning new things & 7 & 10 \\
\hline 3 & Obtaining pedagogical knowledge & 2 & 3 \\
\hline Program planning & & \\
\hline 4 & Faculty members & 9 & 13 \\
\hline 5 & Provision of opportunities/rights & 4 & 6 \\
\hline 6 & Learning environment & 4 & 6 \\
\hline 7 & Duration of the program & 4 & 6 \\
\hline 8 & Relevance of the classes & 2 & 3 \\
\hline Personal and social development & & \\
\hline 9 & Contribution to personal life & 6 & 9 \\
\hline 10 & Gaining perspective & 6 & 9 \\
\hline 11 & Making new friends & 2 & 3 \\
\hline 12 & Gaining awareness & 1 & 1 \\
\hline Employment & & \\
\hline 13 & Job opportunity & 5 & 7 \\
\hline 14 & Obtaining the certificate & 1 & 1 \\
\hline
\end{tabular}

Some examples of the positive views of the participants about the program are presented below:

"Professional knowledge will benefit us in our professional life." (5, Mathematics)

"On the positive side, it enabled us to learn new things, primarily for profession of teaching. (The program) taught 
us how to communicate by taking into consideration the psychological and sociological aspects of our students." $(54$, TLL)

"(The program is) has good staff to train us as good preservice teachers." (16, Mathematics)

"Learning is good, we learn useful things in the program. It is positive that we will apply in the future what we have learned." (64, TLL)

"I think it is useful in many ways in my personal life. I think everything I have learned will be useful in my future life." (23, Mathematics)

"Looking at events from different perspectives, gaining a critical perspective." (30, Chemistry)

\subsection{Difficulties of the Certificate Program for Pedagogical Formation According to the Participants}

The difficulties of CPPF were asked of the participants and findings on the theme of "negative views about the program" were obtained. The negative views of the participants about the program were gathered under the program planning theme. Intensive course and exam schedule ( $\mathrm{f}=44)$ and duration of the program $(\mathrm{f}=21)$ were in the first two places among all negative views that were stated. These views were followed by intensive and verbal content $(\mathrm{f}=8)$, the length of the class hours $(\mathrm{f}=7)$ and the overlap of the program with undergraduate courses ( $\mathrm{f}=6$ ). While the Mathematics and Chemistry groups stated that the content of the courses was too verbal, the Turkish Language and Literature group stated that the intensive course content caused a rote learning environment. Table 4 presents the negative views of the participants about the program.

Table 4. Negative views of the participants about the program

\begin{tabular}{llcc}
\hline & \multicolumn{1}{c}{ Theme } & Program planning & $\%$ \\
\hline 1 & Intensive course and exam schedule & 44 & 64 \\
2 & Duration of the program & 21 & 30 \\
3 & Intensive and verbal content & 8 & 11 \\
4 & Length of the class hours & 7 & 10 \\
5 & Overlaps with undergraduate courses & 6 & 9 \\
6 & Crowded classroom & 4 & 6 \\
7 & Compulsory attendance & 3 & 4 \\
8 & Paid nature of the program & 3 & 4 \\
9 & Physical and psychological fatigue & 3 & 4 \\
10 & Age distribution of the class & 2 & 3 \\
11 & Physical conditions & 2 & 3 \\
12 & Provision of basic needs & 2 & 3 \\
13 & Distance & 2 & 3 \\
\hline
\end{tabular}

Some examples of the negative views of the participants about the program are presented below:

"Since the (course) program was very cramped, we had difficulty because of the intensity of content." (12, Mathematics)

"While it was a very short time frame, the classes were very compressed; it was exhausting to listen to the classes for too long in a row." (49, TLL)

"The curriculum was too intense. If the program had a longer period with the same content, we would have received education with much higher quality." (33, Chemistry)

"(The program was planned along) a very short duration. It is not right to take part in the program for just seven weeks." (10, Mathematics)

"Since we received this training program in short time interval, it led us to obtain more limited information." (36, TLL)

"Time is limited, crash course, the program badly affects the other courses taken at the school in terms of time and motivation." (64, TLL)

"(The classes) are too verbal, and the content is confusing." (8, Mathematics)

"For twelve hours, no student can afford it. (...) Yes, this program has a price, and it is our own decision, but we are 
compelled to do so." (53, TLL)

"The courses are on Friday, Saturday and Sunday, and the class hours are long." (32, Chemistry)

\section{Discussion}

Overall, andragogy appears to be helpful in creating a positive learning environment for young adults on the level of tertiary education. This argument was supported by addressing the two research questions explored in this study as follows.

\section{What are the contributions of the Certificate Program for Pedagogical Formation according to young adults?}

The thoughts that have emerged before in the adult education literature and studies on adults were expressed by the participants in this study. For this reason, it was a significant result of this study that learning took the first place among the participants' expressions about the program's contributions, which were coded as positive views. While the views coded as 'obtaining professional knowledge' pointed to the motivations of the participants towards learning (Houle, 1961), the expression of learning new things by the participants as a positive situation was significant in terms of the interest of adults in learning in a pedagogical learning environment. The participants' second emphasis on the faculty members in the learning environment under the theme of program planning was important in that it highlighted the role of the faculty member in an adult classroom. The finding that faculty members were among the positive aspects of the program that were stated by the participants in this study may be interpreted as that the participants saw the faculty members differently from a typical teacher in a learning environment. Clardy (2005) stated that the role of the instructor should be a process facilitator rather than a content expert in order to create andragogical learning conditions and drew attention to the facilitator function of the instructor in the implementation of the andragogical approach. Freire (2014) argued that the instructor in an adult classroom should also be a student in a sense, and in his words, a teacher-student. This is because adult classrooms are environments where information is shared mutually. Livingston-Galloway and George (2020) promoted andragogical changes in classrooms, culturally and linguistically, as this approach promotes discussion and deliberative learning between the instractor and the student in higher education. Findings that point to the social aspect of participation, such as appreciation and respect for faculty members, the learning environment and making new friends, support research on the reasons for adults to participate (Kaimakami, Panta, Maria \& Kaimakamis, 2008).

\section{What are difficulties of the Certificate Program for Pedagogical Formation according to young adults?}

In this study, the finding that the participants' views on the difficulties of the program were related to program planning showed that the pedagogical arrangements in the program were a challenging situation for them. Thus, the negative views of the participants about the program focused on program planning. The most frequently stated negative aspect in this study was about the class and exam schedule due to the intensive, compact nature of the program. It was reported by the participants that the density of the course and exam schedule affected their learning negatively. In addition to this issue, while the mostly verbal content of the program was challenging for those coming from positive sciences, the participants from humanities stated that the intensive content caused rote learning. While the rote learning view confirmed the view of Freire (2014), it also supported the findings in this study about gaining professional knowledge and learning new things, which were among the positive views stated about the program. The duration of the certificate program is determined as 'at least two semesters' by CoHE (2015), but it was seen that the duration was shortened even more during the implementation phase. The participants stated as a negative view that 'such an important certificate program' was offered in two seven-week semesters, and they thought that the fatigue experienced due to the intensive curriculum and long class hours affected learning negatively. Köse (2017) found that the program discussed here was not suitable for teaching due to its short duration, and the consideration of the certificate as a right by the participants due to the payment of a fee, and therefore, the education process was neglected, causing attendance problems. In the study by Demirtaş and Kırbaç (2016), most participants rated the program as inadequate due to its short duration and being cramped. Adult learners' criticism of the paid program agreed with the criticism of the commodification of education (Williams, 2016). According to the learning orientation principle of andragogy, adults are willing to learn if it will contribute to the solution of a problem in their lives (Knowles, 2009). In this study, the participants stated that certification is important for their professional life and expressed that they wanted to study by digesting the topics and allocating sufficient time for each class. On the other hand, the statement of the participants that such an intensive program led to rote learning and that permanent learning did not take place supported Freire's (2014) views on the traditional education system and the pedagogical understanding of learning. Finally, the participants of this study emphasized the program's contribution to their personal and social development. This connection between learning and life may be seen as a reflection of the tendency of adults to 
be life-centered in their learning orientations, as stated by Knowles (1980).

The answers given by the participants in this study showed the importance of taking the needs and interests of adults into account in learning, as well as in the planning and execution of the certificate program. The critical views of the participants, especially on program planning, pointed to the importance of structuring the program according to the learning characteristics of adults. Additionally, in the findings, factors affecting adult education and learning such as compulsory attendance, the age level of the classroom and physical conditions were also mentioned. Adults learn best in a non-threatening environment and when they have opportunities to control the learning process (Ozuah, 2005). This reveals the importance of the learning environment and learning process. The finding in this study about crowded classrooms supported Armstrong's (2004) view that in adult learning, classrooms should consist of small and homogeneous groups.

\section{Conclusion and Recommendations}

CPPF is a teacher training practice which has been presented under various titles and formats since the 2000s in Turkey. The participants of the program are mostly young adults. However, it is seen that pedagogical principles predominate in the implementation of the program and adult learning methods and techniques are not applied much.

This study aimed to evaluate CPPF, based on the views of young adults who are the participants of the program. The study was carried out with the participation of 69 adult learners. The participants answered questions aimed at determining their views on the program. The answers given by the participants in this study are expected to guide the sustainability of the program.

Given that teachers are valuable for a society, it is important that teacher training is based on andragogical principles and adult learning characteristics. It is recommended for educators to influence students' attitudes towards classes through an andragogical design of the student-centered curriculum. Consequently, the adoption of andragogical approaches in educational activities and learning environments from the beginning of young adulthood, which is also the first period of adulthood, increases participation and interest and affects learning positively.

This study revealed the importance of considering andragogical principles in CPPF. The recommendations developed in light of the findings of this study are as follows:

1) It is recommended for policy makers to plan CPPF in accordance with the learning characteristics of adults and make arrangements in this direction, as well as evaluating the distance education option for the theoretical part of the program to make it possible for graduated adult learners to participate.

2) Since the learning process of adults is different from children, it may be recommended for educators to consider andragogical principles in the learning environment where certificate courses are conducted.

3) It is recommended for researchers to investigate the ways of applying andragogical practices for young adults studying in higher education in different groups other than, teacher training programs. This way, andragogical contents can be designed for higher education programs, and a learning environment can be created for young adults based on their learning characteristics.

\section{References}

Akyüz, Y. (2019). Türk eğitim tarihi (M.Ö. 1000-M.S. 2019) [Turkish educational history (1000 BC - AC 2019)] (31. Bask1). Ankara: Pegem Akademi. https://doi.org/10.14527/9789758792399

Alpan, G. B., Demirkan, O., Koç-Erdamar, G., Yazçayır, N., \& Saraçoğlu, G. (2019). Pedagojik formasyon eğitimi sertifika programı öncesi ve sonrası öğretmen adaylarının ideal öğretmen algıları [Preservice teachers' perceptions of an "ideal teacher" before and after the pedagogical formation training certificate program]. Akdeniz Eğitim Araştırmaları Dergisi, 13(27), 204-218. https://doi.org/10.29329/mjer.2019.185.9

Armstrong, J. L. (2004). Seven keys for small group success. Adult Learning, 15(1/2), 34-35. https://doi.org/10.1177/104515950401500109

Blondy, L. C. (2007). Evaluation and application of andragogical assumptions to the adult online learning environment. Journal of Interactive Online Learning, 6(2), 116-130. Retrieved from https://www.ncolr.org/jiol/issues/pdf/6.2.3.pdf

Büyüköztürk, Ş, Kılıç Çakmak, E.,Akgün, Ö. E., Karadeniz, Ş., \& Demirel, F. (2008). Bilimsel araştırma yöntemleri [Scientific research methods]. Ankara: Pegem Akademi.

Clardy, A. (2005). Andragogy: Adult learning and education at its best? Retrieved from 
https://files.eric.ed.gov/fulltext/ED492132.pdf

Creswell, J. W. (2017). Araştırma deseni: Nitel, nicel ve karma yöntem yaklaşımları [Research design: Qualitative, quantitative and mixed methods approaches] (S. B. Demir, Trans. Ed.). Ankara: Eğiten Kitap.

Demirtaş, H., \& Kırbaç, M. (2016). Pedagojik formasyon sertifika programı öğrencilerinin pedagojik formasyon eğitimine ilişkin görüşleri [The views of pedagogic formation certificate program students regarding pedagogic formation training]. Trakya Üniversitesi Ë̆itim Fakültesi Dergisi, 6(2), 138-152. Retrieved from https://dergipark.org.tr/tr/pub/trkefd/issue/24152/256285

Freire, P. (2014). Ezilenlerin pedagojisi [Pedagogy of oppressed] (D. Hattatoğlu \& E. Özbek, Trans.). İstanbul:Ayrıntı.

Gibbs, G. R. (2007). Analyzing qualitative data. In U. Flick (Ed.), The Sage Qualitative Research Kit. Thousand Oaks, CA: Sage.

Glassner, A., \& Back, S. (2020). Three "Gogies": Pedagogy, andragogy, heutagogy. In Exploring Heutagogy in Higher Education (pp. 59-74). https://doi.org/10.1007/978-981-15-4144-5_5

Glesne, C. (2015). Nitel araştırmaya giriş [Introduction to qualitative research] (A. Ersoy \& P. Yalçınoğlu, Trans. Eds.). Ankara: Anı.

Gürol, M., Türkan, A., \& Som, İ. (2018). Pedagojik formasyon sertifika programının değerlendirilmesi [Evaluation of pedagogical formation certifcate program]. Elektronik Sosyal Bilimler Dergisi, 17(65), 103-122. https://doi.org/10.17755/esosder.306839

Güven, İ. (2014). Türkiye'de Öğretmen Eğitiminin Dönüşümü [Transformation of Teacher Education in Turkey]. In A. Yıldız (Ed.), İdealist Öğretmenden Sinava Hazırlayıcı Teknisyene Öğretmenliğin Dönüsümü [Transformation of Teaching: From Idealist Teacher to Exam Preparation Technician] (pp. 57-95). İstanbul: Kalkedon.

Houle, C. O. (1961). The inquiring mind. Madison: University of Wisconsin Press.

Jarvis, P. (1990). An international dictionary of adult and continuing education. London: Routledge.

Jarvis, P. (2004). Adult education and lifelong learning: Theory and practice (3rd ed.). London: Routledge Falmer. https://doi.org/10.4324/9780203561560

Kaimakami, E., Panta, M., Maria, K., \& Kaimakamis, G. (July, 2008). Factors influencing adults participation in education. Proceedings of the 5th WSEAS/IASME international conference on Engineering education, Heraklion, Greece. Retrieved from http://www.wseas.us/e-library/conferences/2008/crete/education/ education67.pdf

Kasworm, C. E. (2018). Adult Students: A Confusing World in Undergraduate Higher Education. The Journal of Continuing Higher Education, 66(2), 77-87. https://doi.org/10.1080/07377363.2018.1469077

Kılınç, A. Ç., Kılcan, B., \& Çepni, O. (2018). Pedagojik formasyon eğitimi sertifika programına katılan edebiyat fakültesi öğrencilerinin öğretmenlik uygulaması deneyimlerinin incelenmesi: Fenomenolojik bir çözümleme [Examining the teaching practice experiences of students of karabuk university faculty of literature having participated in pedagogical formation certification program: A phenomenological analysis]. Eğitimde Nitel Araştırmalar Dergisi - Journal of Qualitative Research in Education, 6(1), 113-132. https://doi.org/10.14689/issn.2148-2624.1.6c1s5m

Knowles, M. S. (1980). The Modern Practice of Adult Education: From Pedagogy to Andragogy. New Jersey: Cambridge/Prentice Hall Regents.

Knowles, M. S. (1996). Yetişkin ögrenenler gözardı edilen bir kesim [Adult learners a neglected species] (S. Ayhan, Trans.). Ankara: Ankara Üniversitesi Basımevi.

Knowles, M. S. (2009). Andragoji: Yetişkinlerde öğrenme konusunda yeni bir teknoloji [Andragogy: A new technology in adult learning] (S. Ayhan, Trans.). In A. Yıldız, \& M. Uysal (Eds), Yetişskin eğitimi kuramdan uygulamaya [Adult education from theory to practice]. (pp. 127-144). İstanbul: Kalkedon (Translated from Education for Adults, T. Malcolin, Ed., 1983, Cromm Helm London and Cancerra).

Knowles, M. S., Holton, E. F., \& Swanson, R. A. (2005). The adult learner: The definitive classic in adult education and human resource development (6th ed.). Burlington, MA: Elsevier. https://doi.org/10.4324/9780080481913

Korkut, H. (1999). Öğretim üyelerinin pedagojik formasyon gereksinimleri [Pedagogical formation requirements 
of faculty members]. Kuram ve Uygulamada Eğitim Yönetimi, Güz Sayısı (Fall 1999). Retrieved from https://dergipark.org.tr/tr/download/article-file/108543

Köse, A. (2017). Pedagojik formasyon eğitiminde görevli akademisyenlere göre pedagojik formasyon uygulamasi: Sorunlar, çözüm önerileri [The views of academicians who give pedagogical formation education regarding pedagogical formation certificate program: Problems and solution proposals]. Ahi Evran Üniversitesi Kırşsehir Eğitim Fakültesi Dergisi (KEFAD), 18(2), 709-732. Retrieved from https://dergipark.org.tr/en/download/article-file/1486938

Livingston-Galloway, M., \& George, J. (2020). A theoretical perspective of culturally responsive andragogy for international English learners in American higher education institutions. Journal of the Scholarship of Teaching and Learning for Christians in Higher Education, 10(1), 35-52. https://doi.org/10.31380/sotlched.10.1.35

McNally, J. J., Piperopoulos, P., Welsh, D. H. B., Mengel, T., Tantawy, M., \& Papageorgiadis, N. (2019). From pedagogy to andragogy: Assessing the impact of social entrepreneurship course syllabi on the millennial learner. Journal of Small Business Management. https://doi.org/10.1080/00472778.2019.1677059

Merriam, S. B. (2001). Andragogy and self-directed learning: Pillars of adult learning theory. In S. B. Merriam (Ed.), An update on adult learning theory (pp. 3-14). New Directions for Adult and Continuing Education, No. 89. San Francisco: Jossey-Bass. https://doi.org/10.1002/ace.3

Merriam, S. B. (2013). Nitel araştırma desen ve uygulama için bir rehber [Qualitative research a guide to design and implementation] (S. Turan, Trans. Ed.). Ankara: Nobel.

Miles, M. B., \& Huberman, A. M. (1994). Qualitative data analysis: A sourcebook of new methods. Thousand Oaks, CA: Sage.

Nesbit, T., Leach, L., \& Foley, G. (2004). Teaching adults. In G. Foley (Ed.), Dimensions of Adult Learning: Adult education and training in a global era (pp. 74-95). Berkshire: Open University Press. https://doi.org/10.4324/9781003115366-7

Okçabol, R. (2005). Öğretmen yetişstirme sistemimiz [Our teacher training system]. Ankara: Ütopya.

Okçabol, R. (2009). Eğitim bilimlerine girişs [Introduction to educational sciences]. Ankara: Ütopya.

Onur, B. (2006). Gelişim psikolojisi yetişkinlik, yaşlılık, ölüm [Developmental psychology adulthood, old age, death] (7. Baski). Ankara: İmge Kitabevi.

Özkan, H. H. (2012). Öğretmenlik formasyon programındaki öğretmen adaylarının öğretmenlik mesleğine ilişkin tutumlarının incelenmesi (SDÜ örneği) [Investigation of pre-service teachers' attitudes towards teaching profession in a teaching formation certification program (SDÜ sample)]. Ahi Evran Üniversitesi Kirşehir Eğitim Fakültesi Dergisi (KEFAD), 13(2), 29-48. Retrieved from https://dergipark.org.tr/tr/pub/kefad/issue/59489/854975

Ozuah, P. O. (2005). First, There was pedagogy and then came andragogy. The Einstein Journal of Biology and Medicine, 21, 83-87. Retrieved from https://citeseerx.ist.psu.edu/viewdoc/download?doi=10.1.1.492.6336\& rep=rep1\&type $=$ pdf

Patton, M. Q. (2018). Nitel araştırma ve değerlendirme yöntemleri [Qualitative research and evaluation methods] (M. Bütün \& S. B. Demir, Trans. Eds.). Ankara: Pegem Akademi.

Rogers, A. (2014). The Classroom and the everyday: The importance of informal learning for formal learning. Investigar em Educação, 2(1), 7-34. Retrieved from https://www.researchgate.net/publication/311419581 _The_Classroom_and_the_Everyday_The_Importance_of_Informal_Learning_for_Formal_Learning_1

Santos, J., Figueiredo, A. S., \& Vieira, M. (2019). Innovative pedagogical practices in higher education: An integrative literature review. Nurse Education Today, 72, 12-17. https://doi.org/10.1016/j.nedt.2018.10.003

Statistics Canada. (2008). Adult learning in Canada: Characteristics of learners. Retrieved from https://www150.statcan.gc.ca/n1/en/pub/81-004-x/2008001/article/10560-eng.pdf?st=b2RqMrh1

Tepeli, Y., \& Caner, M. (2014). Pedagojik formasyon programı öğrencilerinin öğretmenlik uygulaması ile ilgili görüşleri [Teacher certificate program students' views on teaching practice]. Eğitim Bilimleri Araştırmaları Dergisi, 4(2), 313-328. https://doi.org/10.12973/jesr.2014.42.17

Toiviainen, H., Kersh, N., \& Hyytiä J. (2019). Understanding vulnerability and encouraging young adults to become active citizens through education: The role of adult education professionals. Journal of Adult and 
Continuing Education, 25(1), 45-64. https://doi.org/10.1177/1477971419826116

Williams, G. (2016). Higher education: Public good or private commodity? London Review of Education, 14(1), 131-142. https://doi.org/10.18546/LRE.14.1.12

Yıldırım, A., \& Şimşek, H. (2005). Sosyal bilimlerde nitel araştırma yöntemleri [Qualitative research methods in the social sciences] (Genişletilmiş 5. Bask1). Ankara: Seçkin.

Yüksek Öğretim Kurumu-YÖK [The Council of Higher Education-CoHE]. (2015). Pedagojik formasyon eğitimi sertifika programına ilişkin çerçeve usul ve esaslar [Framework procedures and principles regarding the pedagogical formation education certificate program]. Retrieved from https://www.yok.gov.tr/Sayfalar/ Kurumsal/IdariBirimler/egitim_ogretim_daire_bsk/pedagojik-formasyon-usul-ve-esaslar.aspx

\section{Copyrights}

Copyright for this article is retained by the author(s), with first publication rights granted to the journal.

This is an open-access article distributed under the terms and conditions of the Creative Commons Attribution license (http://creativecommons.org/licenses/by/4.0/). 